\title{
3M Syndrome: A Report of Four Cases in Two Families
}

\author{
Ayla Güven, Ayşe Nurcan Cebeci \\ Göztepe Educational and Research Hospital, Pediatric Endocrinology Clinic, Istanbul, Turkey
}

\begin{abstract}
$3 \mathrm{M}$ syndrome is a rare entity characterized by severe growth retardation, dysmorphic features and skeletal changes as its major components. It is differentiated from other types of dwarfism by its clinical features and by the typical slender long bones and foreshortened vertebral bodies that can be visualized radiographically. $3 \mathrm{M}$ syndrome has an autosomal recessive mode of inheritance. An early diagnosis is important for genetic counseling. In this report, we present four children ( 3 males, 1 female) from two families who were aged between $4^{11 / 12}$ and $10^{11 / 12}$ years and had clinical findings of $3 \mathrm{M}$ syndrome. One of these patients had received growth hormone $(\mathrm{GH})$ treatment which was discontinued due to an inadequate height gain. Physicians should be aware of this entity in the differential diagnosis of children with severe short stature and mild skeletal changes.
\end{abstract}

Key words: 3M syndrome, short stature, slender bones

Conflict of interest: None declared Received: 27.02 .2011

Accepted: 27.05 .2011

\section{Introduction}

3M syndrome (OMIM \#273750) is characterized by severe dwarfism, low birth weight and dysmorphic features. It was first described by Miller, McKusick and Malvaux in 1975 (1). It is rare a syndrome with unknown prevalence. The diagnosis of $3 \mathrm{M}$ syndrome is based on clinical and radiological findings. Intrauterine growth retardation, severe short stature and skeletal changes are the main characteristics of this syndrome.

The aim of this paper is to add four new patients from two different families to the literature on this syndrome.

\section{Case Reports}

\section{Family 1 (Patients 1 and 2) \\ Patient 1}

A 6 6/12-year-old boy was referred to our endocrine clinic for marked short stature. Following an uncomplicated pregnancy, the patient was born at term by Caesarean section because of breech presentation (Table 1). His anthropometric measurements at birth and at admission are given in Table 2 . The patient was the first child of healthy first-cousin parents. His motor and mental development were normal. Physical examination findings were compatible with $3 \mathrm{M}$ syndrome and are presented in Table 1 and in Figures $1 \mathrm{~A}$ and 2A.

Complete blood count and biochemical analysis were unremarkable. Thyroid function tests were in the normal range. The patient was negative for anti-endomysial antibodies (EMA) $\lg \mathrm{A}$. He had a normal response to growth hormone $(\mathrm{GH})$ stimulation test with clonidine (peak GH level was $19.6 \mathrm{ng} / \mathrm{mL}$ ). Physiological GH profile during sleep was within normal limits (mean GH: $7.6 \mathrm{ng} / \mathrm{mL}$ ). Insulin-like growth factor-1 (IGF-1)

\section{Address for Correspondence}


generation test for excluding GH insensitivity syndrome (GHIS) was normal (Table 3). Due to phenotypic findings in this boy and his sister (Case 2), the family was referred for genetic counseling. Radiographic bone survey showed slender long bones with diaphyseal constriction and flared metaphyses, slender ribs, thick cortex of the tibia and femur, tall lumbar vertebrae, a small pelvis, short femoral neck and short iliac wings (Figures 3 and 4). Abdominal ultrasonographic examination was normal.
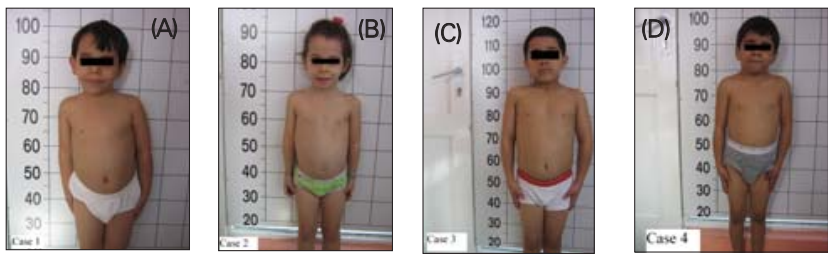

Figure 1. Patients 1 (A), 2 (B), 3 (C) and 4 (D). The patients exhibited the physical findings of $3 \mathrm{M}$ syndrome: Dolichocephaly, high and broad forehead, upswept posterior hairline (in patients 1 and 2), downward slanting of the eyes, horizontal eyebrows, flat nasal bridge, narrowed and short nasal body, prominent fleshy nasal tip, straight clavicles, high and square shoulders, short, wide and flat thorax with a mild pectus excavatum
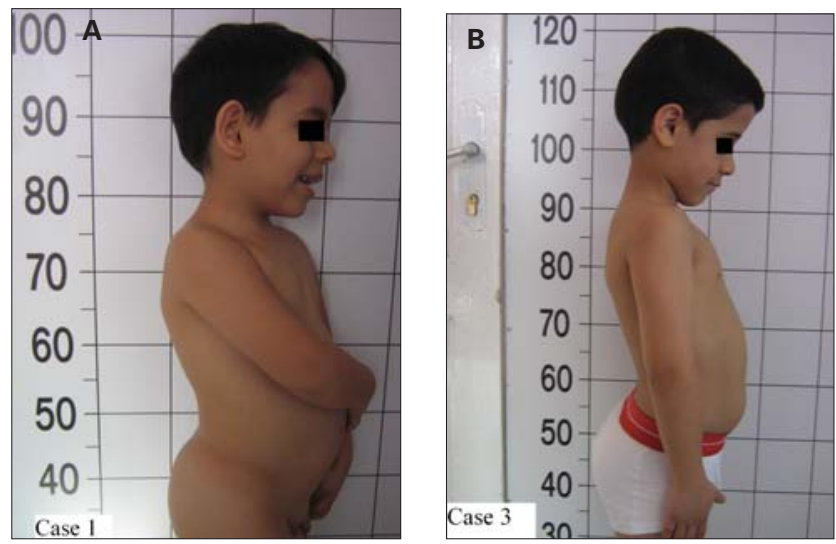

Figure 2. Exaggerated hyperlordosis as seen in Patients $1(A)$ and $3(B)$

\section{Patient 2}

This patient was the younger sister of Patient 1. She was born at term after an uncomplicated pregnancy and Caesarean section because of breech presentation (Table1). Her birth weight and length are given in Table 2. Her developmental milestones were achieved within normal time frames.

Anthropometric measurements at age $4^{11 / 12}$ years are given in Table 2. The findings in her physical examination were very similar to those of her brother (Figure 1B).

Results of complete blood count and biochemical analysis were unremarkable. Thyroid function tests were in the normal range. EMA IgA was negative.

The patient had a normal response to $\mathrm{GH}$ stimulation test with clonidine (peak GH level was $40 \mathrm{ng} / \mathrm{mL}$ ). GHIS was excluded with IGF-1 generation test (Table 3). Skeletal survey showed slender long bones with diaphyseal constriction and flared metaphyses, slender ribs, tall lumbar vertebrae, small pelvis and short iliac wings (Figure 5). Abdominal ultrasonographic examination was normal. The phenotypic findings in these sibs in combination with skeletal radiography and consanguinity in the family led us to a diagnosis of $3 \mathrm{M}$ syndrome. Unfortunately the parents refused molecular genetic analysis.

Family 2 (Patients 3 and 4)

\section{Patient 3}

This $10^{11 / 12}$-year-old boy was referred to our clinic for severe short stature. He was the first child of first-cousin parents. He was born small for gestational age (Table 1). His developmental milestones were achieved within normal limits. He had incomplete response to $\mathrm{GH}$ stimulation as well as to exogenous $\mathrm{GH}$ therapy given for two years in another pediatric endocrinology department and the treatment had been stopped. His physical and skeletal findings were not compatible with $\mathrm{GH}$ deficiency. The skeletal dysplasia was not considered at genetic evaluation at age 9 and $\mathrm{GH}$

\begin{tabular}{|lllll}
\hline Table 1. Data on patient histories & & & & \\
\hline Features & Patient 1 & Patient 2 & Patient 3 & Patient 4 \\
\hline Delivery and presentation & $\begin{array}{l}\text { Breech } \\
\text { (Caesarean section) }\end{array}$ & $\begin{array}{l}\text { Breech } \\
\text { (Caesarean section) }\end{array}$ & $\begin{array}{l}\text { Oligohydramnios } \\
\text { (Caesarean section) }\end{array}$ & Caesarean section \\
Sex & Male & Female & Male & Male \\
Birth weight, kg (SDS) & $2160(-3.77)$ & $2250(-3.22)$ & $2400(-3.08)$ & 2400 (-3.08) \\
Birth length, cm (SDS) & $41(-5.47)$ & $39(-6.35)$ & $44(-3.83)$ & 42 (-4.92) \\
Gestational week & 39 & 39 & Term & Term \\
Parents' relation & First cousins & First cousins & First cousins & First cousins \\
Family history & Maternal grandfather's & Maternal grandfather's & & \\
\end{tabular}

SDS: standard deviation score 
Table 2. Clinical findings of the patients (at diagnosis)

\begin{tabular}{|c|c|c|c|c|}
\hline & Patient 1 & Patient 2 & Patient 3 & Patient 4 \\
\hline Age, years & $6^{2 / 12}$ & $4^{11 / 12}$ & $10^{11 / 12}$ & $74 / 12$ \\
\hline Weight, kg (SDS) & $19.2(-0.60)$ & 13. $(-2.40)$ & $23.5(-2.8)$ & $15(-3.84)$ \\
\hline Height, cm (SDS) & $102.5(-3.19)$ & $93.6(-3.55)$ & $116.1(-5.43)$ & $99.5(-3.84)$ \\
\hline Body mass index & 18.2 & 15 & 17.4 & 15.1 \\
\hline $\begin{array}{l}\text { Head circumference } \\
\mathrm{cm} \text { (percentile) }\end{array}$ & $50(5-10)$ & $49 \mathrm{~cm}(10-25)$ & $53(25)$ & $51(10-25)$ \\
\hline Arm span (cm) & 98 & 89 & 113 & 99 \\
\hline Upper segment (US) (cm) & 57.5 & 54.9 & 64.4 & 57.8 \\
\hline US/LS & 1.27 (>2SD) & 1.41 (>2SD) & 1.24 (>2SD) & 1.38 (>2SD) \\
\hline Bone age (years) ${ }^{*}$ & 5 & $4^{2 / 12}$ & 9 & $3^{6 / 12}$ \\
\hline 10 & Normal & Normal & Normal & Normal \\
\hline \multicolumn{5}{|l|}{ Clinical features } \\
\hline Skull and forehead & $\begin{array}{l}\text { Dolichocephaly, } \\
\text { High and broad forehead, } \\
\text { upswept posterior hairline }\end{array}$ & $\begin{array}{l}\text { Dolichocephaly, } \\
\text { High and broad forehead, } \\
\text { upswept posterior hairline }\end{array}$ & $\begin{array}{l}\text { Dolicocephaly, } \\
\text { High and broad forehead }\end{array}$ & $\begin{array}{l}\text { Dolichocephaly, } \\
\text { High and broad } \\
\text { forehead }\end{array}$ \\
\hline Eyes & $\begin{array}{l}\text { Downward-slanting eyes, } \\
\text { horizontal eyebrows }\end{array}$ & $\begin{array}{l}\text { Downward-slanting eyes, } \\
\text { horizontal eyebrows }\end{array}$ & $\begin{array}{l}\text { Prominent eyebrows, } \\
\text { downward-slanting eyes }\end{array}$ & $\begin{array}{l}\text { Prominent eyebrows, } \\
\text { downward-slanting eyes }\end{array}$ \\
\hline Ears & Normal & Normal & Normal & Normal \\
\hline Nose & $\begin{array}{l}\text { Flat nasal bridge, narrowed } \\
\text { and short nasal body, } \\
\text { prominent fleshy nasal tip }\end{array}$ & $\begin{array}{l}\text { Flat nasal bridge, narrowed } \\
\text { and short nasal body, } \\
\text { prominent fleshy nasal } \\
\text { tip with mild upturned nares }\end{array}$ & $\begin{array}{l}\text { Flat nasal bridge, } \\
\text { narrowed and short } \\
\text { nasal body, prominent } \\
\text { fleshy nasal tip with } \\
\text { upturned nares }\end{array}$ & $\begin{array}{l}\text { Flat nasal bridge, } \\
\text { narrowed and short } \\
\text { nasal body, prominent } \\
\text { fleshy nasal tip with } \\
\text { upturned nares }\end{array}$ \\
\hline Malar region & $\begin{array}{l}\text { Mild midface hypoplasia } \\
\text { with malar flattening }\end{array}$ & $\begin{array}{l}\text { Mild midface hypoplasia } \\
\text { with malar flattening }\end{array}$ & $\begin{array}{l}\text { Mild midface hypoplasia } \\
\text { with malar flattening }\end{array}$ & $\begin{array}{l}\text { Mild midface hypoplasia } \\
\text { with malar flattening }\end{array}$ \\
\hline Philtrum & Long & Long & Long & Long \\
\hline $\begin{array}{l}\text { Palate, lips and } \\
\text { teeth }\end{array}$ & $\begin{array}{l}\text { High-arched palate, } \\
\text { prominent mouth, } \\
\text { slightly full lips, large teeth }\end{array}$ & $\begin{array}{l}\text { High-arched palate, } \\
\text { prominent mouth, } \\
\text { slightly full lips, } \\
\text { large teeth }\end{array}$ & $\begin{array}{l}\text { High-arched palate, } \\
\text { prominent mouth, } \\
\text { moderately full lips, } \\
\text { large teeth }\end{array}$ & $\begin{array}{l}\text { High-arched palate, } \\
\text { prominent mouth, } \\
\text { slightly full lips, } \\
\text { large teeth }\end{array}$ \\
\hline Shoulders & $\begin{array}{l}\text { Straight clavicles, prominent } \\
\text { trapezius: high and } \\
\text { square shoulders }\end{array}$ & $\begin{array}{l}\text { Straight clavicles, } \\
\text { prominent trapezius: } \\
\text { high and square shoulders }\end{array}$ & $\begin{array}{l}\text { Straight clavicles, } \\
\text { prominent trapezius: } \\
\text { high and square shoulders }\end{array}$ & $\begin{array}{l}\text { Straight clavicles, } \\
\text { prominent trapezius: } \\
\text { high and square } \\
\text { shoulders }\end{array}$ \\
\hline Thorax & $\begin{array}{l}\text { Short, wide and flat } \\
\text { thorax with a mild } \\
\text { pectus excavatum }\end{array}$ & $\begin{array}{l}\text { Short, wide and flat } \\
\text { thorax with a mild } \\
\text { pectus excavatum }\end{array}$ & $\begin{array}{l}\text { Short, wide and flat } \\
\text { thorax with a mild } \\
\text { pectus excavatum }\end{array}$ & $\begin{array}{l}\text { Short, wide and flat } \\
\text { thorax with a mild } \\
\text { pectus excavatum }\end{array}$ \\
\hline Spine & Hyperlordosis & Mild hyperlordosis & Hyperlordosis & Mild hyperlordosis \\
\hline Clinodactyly & Bilaterally $5^{\text {th }}$ & ----- & Bilaterally $5^{\text {th }}$ & Bilaterally $5^{\text {th }}$ \\
\hline Feet & $\begin{array}{l}\text { Bilaterally } \\
\text { prominent heels }\end{array}$ & $\begin{array}{l}\text { Bilaterally } \\
\text { prominent heels }\end{array}$ & $\begin{array}{l}\text { Bilaterally } \\
\text { prominent heels }\end{array}$ & $\begin{array}{l}\text { Bilaterally } \\
\text { prominent heels }\end{array}$ \\
\hline Joints & Normal & Normal & Joint hypermobility & Normal \\
\hline Pubertal stage & $\begin{array}{l}\text { Testes size } 1 \mathrm{~mL} / 1 \mathrm{~mL} \text {, } \\
\text { Penis size: } 5.5 \times 1.8 \mathrm{~cm} \text {, } \\
\text { Pubic hair: Tanner I }\end{array}$ & $\begin{array}{l}\text { Breast size: Tanner I**, } \\
\text { Pubic hair: Tanner I }\end{array}$ & $\begin{array}{l}\text { Testes size: } 2 \mathrm{~mL} / 2 \mathrm{~mL} \text {, } \\
\text { Penis size: } 5.5 \times 2 \mathrm{~cm}\end{array}$ & $\begin{array}{l}\text { Testes size: } 0.5 \mathrm{~mL} / 0.5 \\
\mathrm{~mL} \text {, Penis size: } 5.5 \times 2 \mathrm{~cm}\end{array}$ \\
\hline
\end{tabular}


therapy was recommended. GHIS was excluded with IGF-1 generation test (Table 3).

The patient's anthropometric and physical examination findings are given in Table 1 and in Figures 1C, 2B and 6.

His biochemical and hormonal results were within normal limits. Skeletal survey of the patient showed slender long bones with diaphyseal constriction and flared metaphyses, slender ribs, thick cortex in the tibia and femur, short femoral neck, tall lumbar vertebrae, small pelvis and short iliac wings (Figure 7).

\section{Patient 4}

This boy was the younger brother of Patient 3 (Figure 1D). At admission, the patient was 74/12 years old. He suffered from short stature, as his brother. His weight and length at birth and at admission are given in Tables 1 and 2. His developmental milestones were achieved within normal limits. The boy had testicles small for his age. He had a normal response to $\mathrm{GH}$ stimulation test with clonidine (peak GH level was $18.2 \mathrm{ng} / \mathrm{mL}$ ). GHIS was excluded with IGF-1 generation test (Table 3). Skeletal survey showed slender long bones with diaphyseal constriction and flared metaphyses, slender ribs, hypoplasia of the $12^{\text {th }}$ ribs, tall lumbar vertebrae, short femoral neck, a small pelvis, and short iliac wings (Figure 8). Abdominal ultrasonography was normal. The diagnosis of $3 \mathrm{M}$ syndrome was established. Genetic analysis could not be performed because the family moved to a different city.

\section{Discussion}

Four patients from two different families who all suffered from severe short stature are presented in this report. All patients were also born small for gestational age. The clinical, radiographic and biochemical findings of all 4 patients conformed the findings characteristic for $3 \mathrm{M}$ syndrome.

$3 \mathrm{M}$ syndrome is characterized by a triangular-shaped face with frontal bossing, mild malar hypoplasia, and narrowed nasal body with a fleshy tip, upturned nares and full lips. Patients usually have large heads for their height, dolichocephaly and normal intelligence. Other clinical findings are a short wide thorax, brachydactyly, clinodactyly, micromelia, prominent heels and a slightly increased upper to lower segment ratio. Both sexes are affected equally. No hormonal deficiencies are detected. Skeletal changes include tall vertebral bodies and

Table 3. Results of the IGF-1 generation tests

\begin{tabular}{lcccc}
\hline & Patient 1 & Patient 2 & Patient 3 & Patient 4 \\
\hline Day 0 IGF-1 (ng/mL) & 121 & 142 & 332 & 305 \\
Day 4 IGF-1 (ng/mL) & 135 & 122 & 880 & 673 \\
Day 0 IGFBP-3 (ng/mL) & 4613 & 6511 & 6888 & 5363 \\
Day 4 IGFBP-3 (ng/mL) & 4573 & 6824 & 5093 & 3411
\end{tabular}

IGF-1: insulin-like growth factor-1, IGFBP-3: IGF binding protein-3

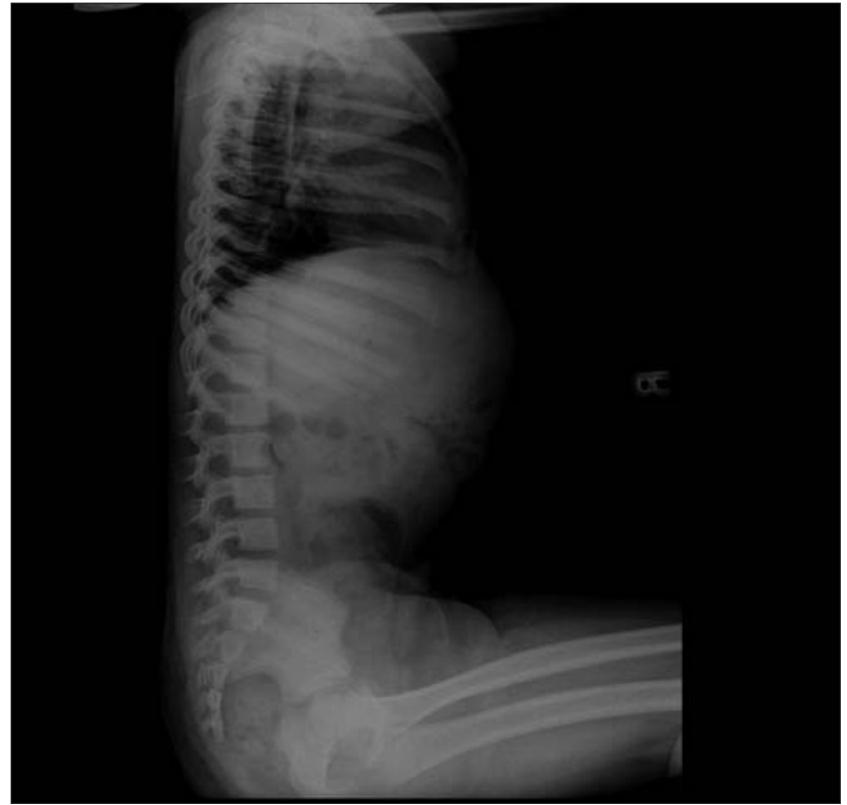

Figure 3. Lateral radiography of the vertebrae showing tall vertebral bodies with reduced anterior-posterior diameters (Patient 1)

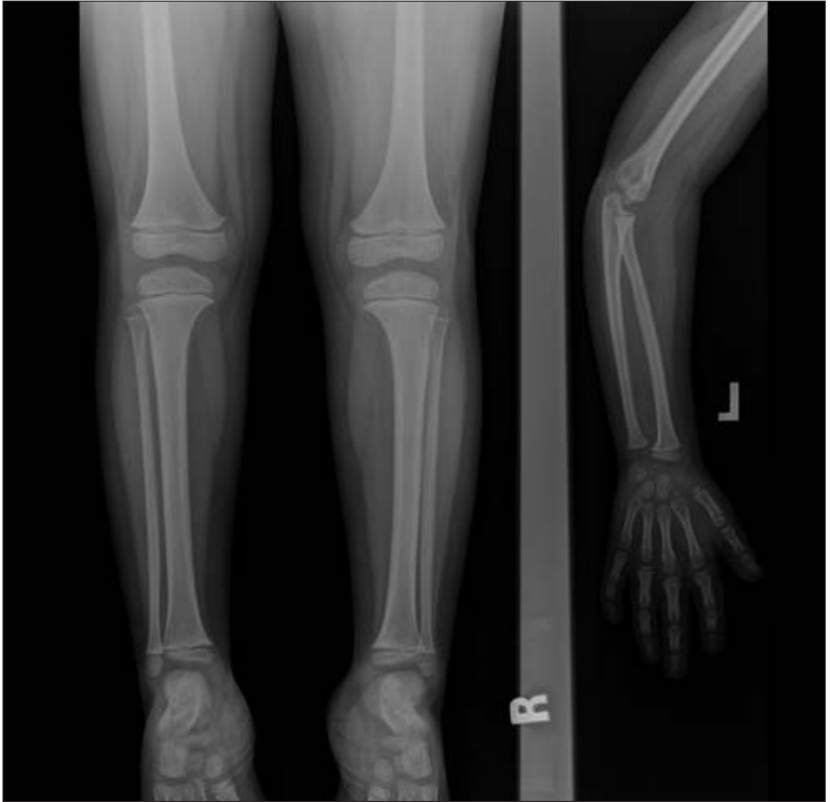

Figure 4. Radiography of the upper and lower extremities showing slender long bones (Patient 1) 
cylindrical long bones with thin diaphyses. The radiographic examination, though abnormal, is not diagnostic as similar X-ray changes have been documented in other disorders $(2,3,4)$.

The patients with $3 \mathrm{M}$ syndrome cannot be easily diagnosed due to slightly dysmorphic facial features and normal intelligence. All four cases were diagnosed after multiple visits and follow-up by different disciplines including genetic evaluation

Presence of $\mathrm{GH}$ deficiency is usually evaluated in patients with $3 \mathrm{M}$ syndrome. Miller et al (1) have reported one patient with partial $\mathrm{GH}$ deficiency. All patients presented here underwent $\mathrm{GH}$ stimulation tests and normal $\mathrm{GH}$ responses were obtained in all except Patient 3. This boy was treated with $\mathrm{GH}$ for two years, however, an insufficient growth response was observed and the therapy was discontinued. IGF-1 generation test was also performed to exclude growth hormone insensitivity. The GHIS is characterized by hypoglycemic episodes, severe growth failure, and a typical craniofacial appearance. Biochemically, GH levels are elevated combined with extremely low levels of IGF-1, IGF-binding protein-3 (IGFBP-3), and IGF-2. GHIS is confirmed by the failure of exogenously administered $\mathrm{GH}$ to elevate the levels of IGF-1 or IGFBP-3 significantly. Although no hypoglycemic episodes and typical craniofacial appearance were present in any of our patients, they all had severe growth failure; therefore, they underwent IGF-1 generation tests.

Gloomy face syndrome and dolichospondylic dysplasia formerly were reported as entities different from 3M

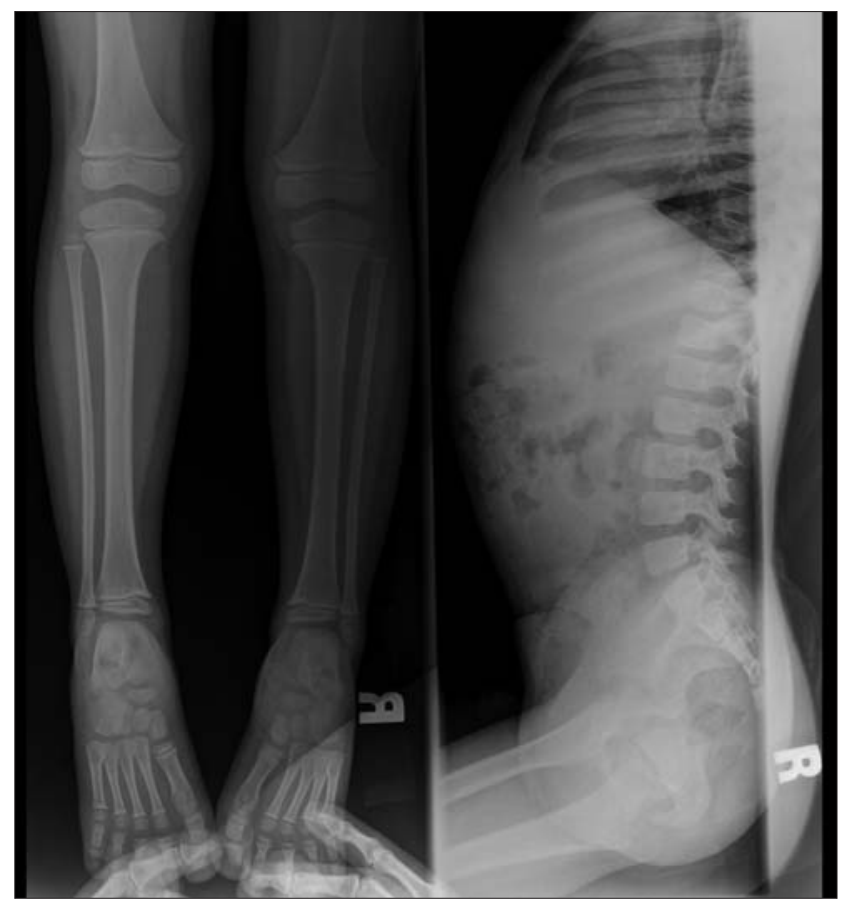

Figure 5. Radiography of the lower extremity and lateral vertebrae in Patient 2 syndrome $(5,6)$. Nowadays, the clinical and radiographic findings of both disorders are found to overlap with $3 \mathrm{M}$ syndrome and, 3M syndrome, gloomy face syndrome and dolichospondylic dysplasia have the same OMIM identification number $(5,6)$.

Physical findings of several entities such as Silver-Russell syndrome (SRS) and Mulibrey nanism are similar to $3 \mathrm{M}$ syndrome. SRS has many similarities with 3M syndrome, e.g. intrauterine growth retardation, short stature, triangular face, relatively large skull, asymmetry of body or limbs and clinodactyly. Mild mental retardation also can be found in patients with SRS. However, abnormalities of the skeletal system have not been reported. Some cases with SRS have maternal disomy for chromosome 7. Chromosomes 11 and 17 are also consistently involved in individuals fulfilling strict diagnostic criteria of SRS (7). Recurrence in a sibship is much less frequent. Adult height of patients with SRS can be as tall as $140 \mathrm{~cm}$, while patients with 3M syndrome do not reach a height greater than $130 \mathrm{~cm}$.

Mulibrey nanism (muscle-liver-brain-eye) is an autosomal recessive disorder characterized by prenatal and postnatal growth retardation, relatively large hands, and triangular facies with frontal bossing. Depressed nasal bridge, elongated sella turcica, and cystic bone changes of the tibiae are also common findings of the syndrome (8).

Maksimova et al (9) have reported 43 patients with short stature, hydrocephaloid skull and typical face in an isolated Yakut population. Although clinical findings were similar to 3M syndrome, slender long bones and tall vertebral bodies have not been commonly observed in this short stature syndrome in Yakuts (9).

Bone age, estimated by the Greulich and Pyle method, was found to be markedly decreased in only one of our male patients. Delayed bone age $(2,10)$ as well as bone age concordant with chronological age (3) have been reported in 3M syndrome patients.

Testicles small for pubertal stage, oligo-azoospermia and hypergonadotropic hypogonadism have been reported in

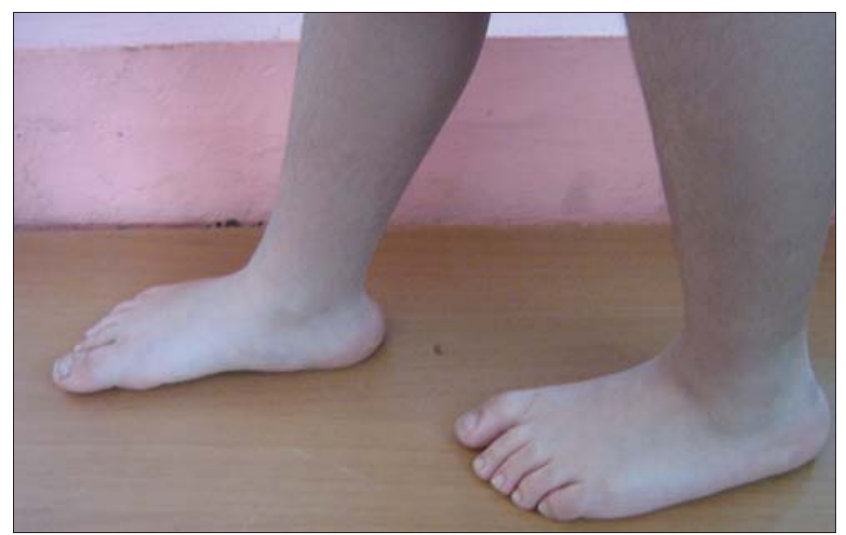

Figure 6. Prominent heels were present in all patients 
males with 3M syndrome (10). Females usually have normal gonadal functions. All 3 of our male patients also had testes small for their age, suggesting gonadal dysfunction. Unfortunately, we were not able to perform any hormonal investigations to evaluate gonadal function.

Skeletal changes are frequently reported in $3 \mathrm{M}$ syndrome. Slender long bones and ribs, foreshortened lumbar vertebral bodies, tall vertebral bodies, short femoral neck, spina bifida occulta, small pelvis, small iliac wings and osteoporosis are common findings $(1,2,3,10)$. Distal shortening of the ulna and kyphoscoliosis are rarely reported in these patients (2). Our patients all showed the radiological features of the syndrome except for spina bifida occulta, shortening of the ulna and kyphoscoliosis.

The mode of inheritance is autosomal recessive in $3 \mathrm{M}$ syndrome. CUL7 mutation in 6p21.1. has been found in several families $(9,11)$. Recently, null mutations within the gene OBSL1 have also been reported (12). OBSL1 is a putative cytoskeletal adaptor protein that localizes to the nuclear envelope OBSL1 and it has been proposed that its mutations are causing the primordial growth disorder $3 \mathrm{M}$ syndrome (12). However, we were not able to perform genetic analyses in the patients presented in this report.

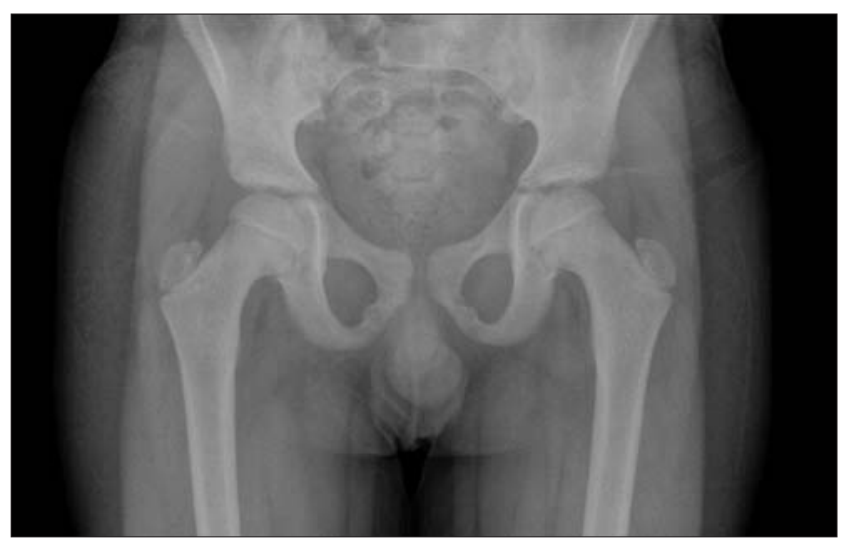

Figure 7. Note the narrow pelvis, hypoplastic pubis and ilium, as well as the short femoral necks (Patient 3)

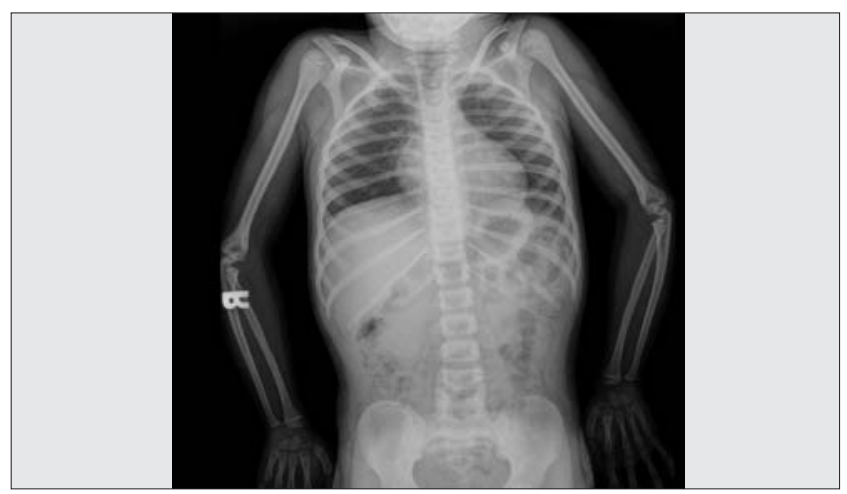

Figure 8. Radiography of the thoracolumbar spine in Patient 4 showing hypoplasia of the $12^{\text {th }}$ ribs
An early diagnosis is important for genetic counseling in $3 \mathrm{M}$ syndrome, especially in countries like Turkey where consanguineous marriages are common and autosomal recessive genetic disorders leading to severe short stature should be kept in mind. 3M syndrome should always be considered in the differential diagnosis of patients with growth retardation of prenatal onset.

\section{References}

1. Miller JD, McKusick VA, Malvaux P, Temtamy S, Salinas C. The 3M syndrome: a heritable low birthweight dwarfism. Birth Defects Orig Artic Ser 1975;11:39-47.

2. Hennekam RC, Bijlsma JB, Spranger J. Further delineation of the $3 \mathrm{M}$ syndrome with review of the literature. Am J Med Genet 1987;28:195-209.

3. Temtamy SA, Aglan MS, Ashour AM, Ramzy MI, Hosny LA, Mostafa MI. 3M syndrome: a report of three Egyptian cases with review of the literature. Clin Dysmorphol 2006;15:55-64.

4. Spranger J, Opitz JM, Nourmand A. A new familial intrauterine growth retardation syndrome the "3M syndrome". Eur J Pediatr 1976;123:115-124.

5. Le Merrer M, Brauner R, Maroteaux P. Dwarfism with gloomy face: a new syndrome with features of $3 \mathrm{M}$ syndrome. J Med Genet 1991;28;186-191.

6. Elliott AM, Graham JM Jr, Curry $C J$, Pal T, Rimoin DL, Lachman RS. Spectrum of dolichospondylic dysplasia: two new patients with distinctive findings. Am J Med Genet 2002;113:351-361.

7. Eggermann $T$, Begemann $M$, Binder $G$, Spengler $S$. Silver-Russell syndrome: genetic basis and molecular genetic testing. Orphanet J Rare Dis 2010;5:19.

8. Karlberg N, Jalanko H, Perheentupa J, Lipsanen-Nyman M. Mulibrey nanism: clinical features and diagnostic criteria. J Med Genet 2004;41:92-98.

9. Maksimova N, Hara K, Miyashia A, Nikolaeva I, Shiga A, Nogovicina A, Sukhomyasova A, Argunov V, Shvedova A, Ikeuchi T, Nishizawa M, Kuwano R, Onodera O. Clinical, molecular and histopathological features of short stature syndrome with novel CUL7 mutation in Yakuts: new population isolate in Asia. J Med Genet 2007;44:772-778.

10. van der Wal G, Otten BJ, Brunner HG, van der Burgt I. 3M syndrome: description of six new patients with review of the literature. Clin Dysmorphol 2001;10:241-252.

11. Hanson D, Murray PG, Sud A, Temtamy SA, Aglan M, Superti-Furga A, Holder SE, Urquhart J, Hilton E, Manson FD, Scambler P, Black GC, Clayton PE. The primordial growth disorder $3 \mathrm{M}$ syndrome connects ubiquitination to the cytoskeletal adaptor obscurin-like 1. Am J Hum Genet 2009;84:801-806.

12. Huber C, Delezoide AL, Guimiot F, Baumann C, Malan V, Le Merrer M, Da Silva DB, Bonneau D, Chatelain P, Chu C, Clark $R$, Cox $H$, Edery $P$, Edouard $T$, Fano V, Gibson K, Gillessen-Kaesbach G, Giovannucci-Uzielli ML, GraulNeumann LM, van Hagen JM, van Hest L, Horovitz D, Melki $J$, Partsch CJ, Plauchu H, Rajab A, Rossi M, Sillence D, Steichen-Gersdorf E, Stewart H, Unger S, Zenker M, Munnich A, Cormier-Daire V. A large-scale mutation search reveals genetic heterogeneity in 3M syndrome. Eur J Hum Genet 2009;17:395-400. 